\title{
Impact of Gelation Conditions and Structural Breakdown on the Physical and Sensory Properties of Stirred Yogurts
}

\author{
W.-J. Lee and J. A. Lucey ${ }^{1}$ \\ Department of Food Science, University of Wisconsin-Madison, 1605 Linden Drive, Madison 53706
}

\begin{abstract}
The objectives of this research were to understand structure-function relationships between the initial yogurt gels and stirred yogurts made from these gels. Yogurt gels were made from milk preheated at 75 or $85^{\circ} \mathrm{C}$ for $30 \mathrm{~min}$ and incubated at 32,38 , or $44^{\circ} \mathrm{C}$. Yogurt gels were sheared at $5 \mathrm{~s}^{-1}$ for 1 min to make stirred yogurts. Small amplitude oscillatory rheology and shear rate sweeps (flow curves) were performed to determine the dynamic moduli and apparent viscosity of yogurts, respectively. Confocal scanning laser microscopy was used to examine the microstructure. The sensory properties of stirred yogurts were determined using quantitative descriptive analysis. Yogurt gels made from high preheating temperatures and low incubation temperatures tended to have an increase in storage modulus, apparent viscosity values at structural breakdown, yield stress, and a decrease in the maximum in loss tangent values and permeability. During the shearing of intact gels, there was an initial increase in apparent viscosity in the low shear rate region, because of the resistance derived from the intact network; commonly used models for stirred yogurts could not adequately describe this type of viscoelastic behavior. Increasing milk preheating temperature and decreasing incubation temperature resulted in stirred yogurts with increased apparent viscosity, oral viscosity, and sensory mouth coating attributes. Storage modulus values of the initial gels were positively correlated with the apparent viscosity at $10 \mathrm{~s}^{-1}(\mathrm{r}=0.61)$, oral viscosity $(\mathrm{r}=$ $0.77)$, and mouth coating sensory attributes $(r=0.72)$ of stirred yogurts. A significant negative correlation was observed between maximum in loss tangent values of initial gels and shear stress values $(r=-0.68)$ of gels at structure breakdown, and in stirred yogurts, the oral viscosity $(\mathrm{r}=-0.85)$, and apparent viscosity at $10 \mathrm{~s}^{-1}$ $(\mathrm{r}=-0.78)$. Permeability was negatively correlated with the oral viscosity $(\mathrm{r}=-0.84)$ and apparent viscosity at $10 \mathrm{~s}^{-1}(\mathrm{r}=-0.82)$ in stirred yogurts. These highly
\end{abstract}

Received November 28, 2005.

Accepted February 16, 2006.

${ }^{1}$ Corresponding author: jalucey@facstaff.wisc.edu significant correlations demonstrated that the structure of the initial gel network and structural breakdown process had a major impact on the physical and sensory attributes of stirred yogurts. The presence of a yield stress and the elastic nature of gels at low strains resulted in commonly used models that could not adequately predict the behavior in the very low shear rate region, although they were able to predict the remainder of the flow profile.

Key words: yogurt, rheology, sensory evaluation

\section{INTRODUCTION}

Yogurts are prepared by the fermentation of milk by lactic acid bacteria, which results in the $\mathrm{pH}$ of milk decreasing to $\mathrm{pH} \leq 4.6$. Industrially, yogurts can be largely divided into 2 types. A set-style yogurt is made in retail containers giving a continuous undisturbed gel structure in the final product. In stirred yogurt manufacture, the gel is disrupted by stirring (agitation) before mixing with fruit and then it is packaged. Stirred yogurts should have a smooth and viscous texture (Tamime and Robinson, 1999).

An understanding of the textural properties of food products can be obtained by a study of the rheological and microstructural properties, as well as the investigation of relationships between the information obtained from instrumental tests and sensory attributes determined by consumers (Bourne, 2002). Large deformation and fracture characteristics of gels are related to sensory perception of gels, such as eating characteristics (van Vliet and Walstra, 1995).

Textural attributes, including the desired oral viscosity, are important criteria for quality and consumer acceptance of yogurt. The physical properties of stirred yogurt, including viscosity, are affected by the original gel properties (Walstra, 1998); in the absence of stabilizers, controlling the gelation process is an important aspect for regulating the textural attributes of the final yogurt product. To control the functional performance (e.g., viscosity and smoothness) of stirred yogurts, it is necessary to understand structure-function relationships during gelation (i.e., fermentation stage) and after the gel is disrupted to make the stirred yogurt. 
The viscosities and flow properties of stirred yogurt have been studied by many researchers (Skriver et al., 1993, 1999; Skriver, 1995; Afonso and Maia, 1999; van Marle et al., 1999; Haque et al., 2001). In these studies, the original yogurt gels were empirically stirred before testing the viscosity. For example, Skriver et al. (1993) and van Marle et al. (1999) reported that their original set gels were stirred using a high-speed mixer or a spoon (20 times), respectively. When stirred yogurt was loaded on the rheometer or viscometer for flow testing, there was further damage to the yogurt structure, which affected the flow properties. Therefore, important information on the structural changes during the breakdown process is lacking. To our knowledge, quantitative relationships between the structural properties of original yogurt gels, which have been extensively studied by small deformation rheological methods, and stirred yogurts made from these (intact) gels have not been adequately studied. To study the structural breakdown (SB) of the initial gel network, gels will be made in situ in a rheometer and then disrupted in the rheometer by shearing while determining fundamental rheological properties.

The aims of this study were to understand the relationships between the physical and microstructural properties of original (intact) yogurt gels and stirred yogurt. Yogurt gels were prepared with different preheating and incubation temperatures to determine how variations in the physical properties of yogurt gels affect rheological and sensory attributes of stirred yogurts.

\section{MATERIALS AND METHODS}

\section{Preparation of Reconstituted Skim Milk and Heat Treatment}

Reconstituted skim milk (10.5\%, wt/wt) was prepared by dissolving low-heat skim milk powder (Dairy America, Fresno, CA) into distilled and deionized water. The whey protein nitrogen index of the low-heat NDM was $7.6 \mathrm{mg}$ of undenatured whey protein/g of powder (Bradley et al., 1992). Skim milks were heated at 75 or $85^{\circ} \mathrm{C}$ for 30 min using a thermostatically controlled water bath. After heating, milks were cooled to $5^{\circ} \mathrm{C}$ in ice water, and stored in a refrigerator until use.

\section{Preparation of Yogurt Gel and Stirred Yogurt}

Yogurt gels were prepared using a commercial yogurt culture (YC-087, Chr. Hansen, Inc., Milwaukee, WI), which mainly includes Streptococcus thermophilus and Lactobacillus delbrueckii ssp. bulgaricus. Stock cultures and working cultures were prepared as described by Lee and Lucey (2004a). Skim milks, preheated at 75 or $85^{\circ} \mathrm{C}$ for $30 \mathrm{~min}$, were inoculated with $2 \%$ (wt/wt) of working culture and incubated at 32,38 , or $44^{\circ} \mathrm{C}$ until $\mathrm{pH} 4.6$ was reached. During fermentation, $\mathrm{pH}$ of milk was continuously recorded using a model PCM 700 Orion Sensor Link system (Orion Research, Beverly, MA).

At the end of fermentation ( $\mathrm{pH} \sim 4.6$ ), $100 \mathrm{~g}$ of intact yogurt gel, made in $250-\mathrm{mL}$ plastic beakers, was cooled to $15^{\circ} \mathrm{C}$ in ice water. The yogurt gel was then stirred using a Maxima digital stirrer (Fisher Scientific, Pittsburgh, PA), using a 3-blade stirring shaft (55 mm diameter), at $5 \mathrm{~s}^{-1}$ for $1 \mathrm{~min}$. Stirred yogurt was then cooled to $5^{\circ} \mathrm{C}$ and stored in a refrigerator for $1 \mathrm{~d}$ before testing.

\section{Rheological Measurements}

Gel formation during yogurt fermentation was monitored using a Universal Dynamic Spectrometer (Paar Physica UDS 200, Physica Messtechnik GmbH, D70567, Stuttgart, Germany). Small amplitude oscillatory rheology with the measurement of storage modulus $\left(\mathbf{G}^{\prime}\right)$ and loss tangent $(\mathbf{L T})$ can be used to characterize the rheological properties of yogurts without damaging the gel network (Roefs et al., 1990; Lee and Lucey, 2004a). The profiled cup and bob measuring geometry, which consisted of 2 coaxial cylinders (diameters 25.0 and $27.5 \mathrm{~mm}$ ), was used to prevent possible slippage of samples during testing. Thirteen milliliters of inoculated milk was transferred to the cup of the rheometer and vegetable oil was used to cover the surface of milk to prevent evaporation. During fermentation, yogurt gels were oscillated at a frequency of $0.1 \mathrm{~Hz}$ and with an applied strain of $1 \%$, which was within the linear viscoelastic range of this type of gel network (van Marle and Zoon, 1995). Gelation was arbitrarily defined as the moment when the $\mathrm{G}^{\prime}$ value of gels was greater than $1 \mathrm{~Pa}$ (e.g., Lucey et al., 1998; Lee and Lucey, 2004b).

The large deformation properties of yogurt gels formed in situ were determined by applying a single, constant shear rate $\left(0.01 \mathrm{~s}^{-1}\right)$ up to the yielding of gel as described by Lucey et al. (1997b). Yield stress ( $\left.\sigma_{\text {yield }}\right)$ was characterized as the point when shear stress value began to decrease, and yield strain $\left(\gamma_{\text {yield }}\right)$ was the corresponding strain value at this point. To determine the effect of the timescale of applied deformation on $\sigma_{\text {yield }}$ and $\gamma_{\text {yield }}$ of yogurt gels, several different single constant shear rates $\left(0.01,0.03,0.05\right.$, and $\left.0.07 \mathrm{~s}^{-1}\right)$ were applied to gels made in situ (i.e., a new undisturbed gel was used for each single shear rate test). The effect of timescale of applied deformation on $\sigma_{\text {yield }}$ and $\gamma_{\text {yield }}$ of yogurt gels was also investigated with the use of continuously increasing shear rates ranging from 0.01 to $0.07 \mathrm{~s}^{-1}$; samples were sheared for $20 \mathrm{~s}$ at each shear rate before starting the next shear rate interval. 
Shear rate sweeps were also performed on intact gels (i.e., gels were made in the rheometer and not stirred before testing). Before shearing, yogurt gels (once they reached $\mathrm{pH} \sim 4.6$ ) were cooled to $15^{\circ} \mathrm{C}$ at a rate of $1^{\circ} \mathrm{C}$ per min. A shear rate sweep, ranging from 0.01 to 600 $\mathrm{s}^{-1}$ on a logarithmic scale (no time setting), was applied to the initial intact yogurt gels at $15^{\circ} \mathrm{C}$. In the manufacture of stirred yogurt, the initial yogurt is usually cooled to $\sim 20^{\circ} \mathrm{C}$ with only slow agitation, and once partially cooled more shear is applied (Lucey, 2004). Excessive shear at high temperature can result in considerable loss of viscosity (Lucey, 2004).

For the shear rate sweep test of stirred yogurt, samples were stored in refrigerator at $5^{\circ} \mathrm{C}$ for $1 \mathrm{~d}$ and were then stirred using a digital overhead stirrer with a speed of $5 \mathrm{~s}^{-1}$ for $1 \mathrm{~min}$ just before the test. Stirred yogurts were gently placed into the cup of the rheometer. Vegetable oil was used to cover the surface of stirred yogurts to prevent evaporation. Stirred yogurts were kept at $5^{\circ} \mathrm{C}$ for $1 \mathrm{~h}$ to allow some degree of structure rebodying before testing, and they were subjected to a shear rate sweep $\left(0.01\right.$ to $\left.600 \mathrm{~s}^{-1}\right)$.

Flow curves were fitted with several rheological models (Mezger, 2002) including the Casson, Carreau, Cross, and Herschel-Bulkley models:

$$
\begin{aligned}
& \text { Casson model: } \sigma^{1 / 2}=\sigma_{c}^{1 / 2}+\left(\eta_{c} \cdot \dot{\gamma}\right)^{1 / 2} \\
& \text { Carreau model: } \frac{\eta-\eta_{\infty}}{\eta_{0}-\eta_{\infty}}=\frac{1}{\left[1+(c \cdot \dot{\gamma})^{2}\right]^{p}} \\
& \text { Cross model: } \frac{\eta-\eta_{\infty}}{\eta_{0}-\eta_{\infty}}=\frac{1}{1+(\kappa \cdot \dot{\gamma})^{p}}
\end{aligned}
$$$$
\text { Herschel-Bulkley model: } \sigma=\sigma_{o}+K(\dot{\gamma})^{n}
$$

where $\sigma=$ shear stress, $\sigma_{c}=$ Casson yield stress, $\eta_{c}=$ Casson viscosity, $\dot{\gamma}=$ shear rate, $\eta=$ dynamic viscosity, $\eta_{0}=$ viscosity for $\dot{\gamma} \rightarrow 0, \eta_{\infty}=$ viscosity for $\dot{\gamma} \rightarrow \infty, c=$ Carreau constant, $\kappa=$ Cross constant, $p=$ exponent, $\sigma_{o}=$ yield stress, $K=$ flow coefficient, and $n=$ Herschel Bulkley index.

The applicability of these rheological models to the flow curves of stirred yogurts was investigated using the sum of square residuals with 18 flow curves ( 3 replicates $\times 6$ experimental conditions).

\section{Permeability}

The permeability coefficient $(\boldsymbol{B})$ of yogurt gels was measured according to the method of Roefs et al. (1990), as described by Lee and Lucey (2004a).

\section{Confocal Scanning Laser Microscopy}

The microstructures of yogurt gels were observed using confocal scanning laser microscopy (CSLM), operated in fluorescence mode as described by Lee and Lucey $(2004 b)$. In the preparation of stirred yogurt for CSLM testing, yogurt gels that had been made with preheated milk, starter culture, and acridine orange (dye), were cooled to $15^{\circ} \mathrm{C}$ using ice water and then sheared at $5 \mathrm{~s}^{-1}$ for $1 \mathrm{~min}$ with an overhead stirrer. Stirred yogurt for CSLM testing was cooled to $5^{\circ} \mathrm{C}$ and stored in a refrigerator for $1 \mathrm{~d}$. Just before testing, this stirred yogurt was stirred at $5 \mathrm{~s}^{-1}$ for 1 min with an overhead stirrer. A few drops of stirred yogurt mixture were transferred to a slide with a cavity and were kept at $5^{\circ} \mathrm{C}$ for $1 \mathrm{~h}$ before testing. Gels and stirred yogurts were observed using a BioRad MRC 1024 confocal scanning laser microscope (BioRad, Hemel Hempstead, UK) equipped with an air-cooled $\mathrm{Ar} / \mathrm{Kr}$ laser, which was used with excitation wavelength of $488 \mathrm{~nm}$ and with a $60 \times$ oil immersion objective (numerical aperture $=1.4$ ). At least 4 microstructure images were obtained for each sample and representative micrographs were reported.

\section{Sensory Evaluation}

Sensory properties of stirred yogurts, which had been stored at $5^{\circ} \mathrm{C}$ for $1 \mathrm{~d}$, were evaluated using quantitative descriptive analysis (Lawless and Heymann, 1998). A trained panel consisting of 10 judges evaluated the sensory attributes of stirred yogurts. The sensory attributes of stirred yogurts were scored on a $150-\mathrm{mm}$ unstructured scale with anchor points $15 \mathrm{~mm}$ from each other. A sensory panel generated 4 sensory attributes, oral viscosity, mouth coating, chalkiness, and visual particle size, during the initial 6 training sessions $(\sim 9$ h). Oral viscosity was defined as perceived degree of thickness when yogurt was squeezed between tongue and the roof of the mouth and sheared during the back and forth motions of the tongue. Commercial drinkable 1\% low-fat yogurt (Stonyfield Farm, Inc., Londonderry, $\mathrm{NH}$ ) and $2 \%$ low fat custard-style yogurt (Yoplait, Inc., Minneapolis, MN) were used as reference standards, which gave watery and thick oral viscosities, respectively. Mouth coating was defined as the afterfeel, film covering the mouth surface. Reference standards representing low and high mouth-coating attributes were drinkable $1.5 \%$ low fat yogurt (Dannon, Inc., White Plains, NY) and plain 1.5\% low fat yogurt (Dannon, Inc.) that was stirred using a Maxima digital stirrer (Fisher Scientific, Pittsburgh, PA) at $15 \mathrm{~s}^{-1}$ for $1 \mathrm{~min}$. The presence of very fine particles on the tongue was defined as chalkiness. Two percent low fat custard-style yogurt (Yoplait, Inc.) and plain 1.5\% low fat yogurt (Dannon, Inc.) were used as reference standards indi- 


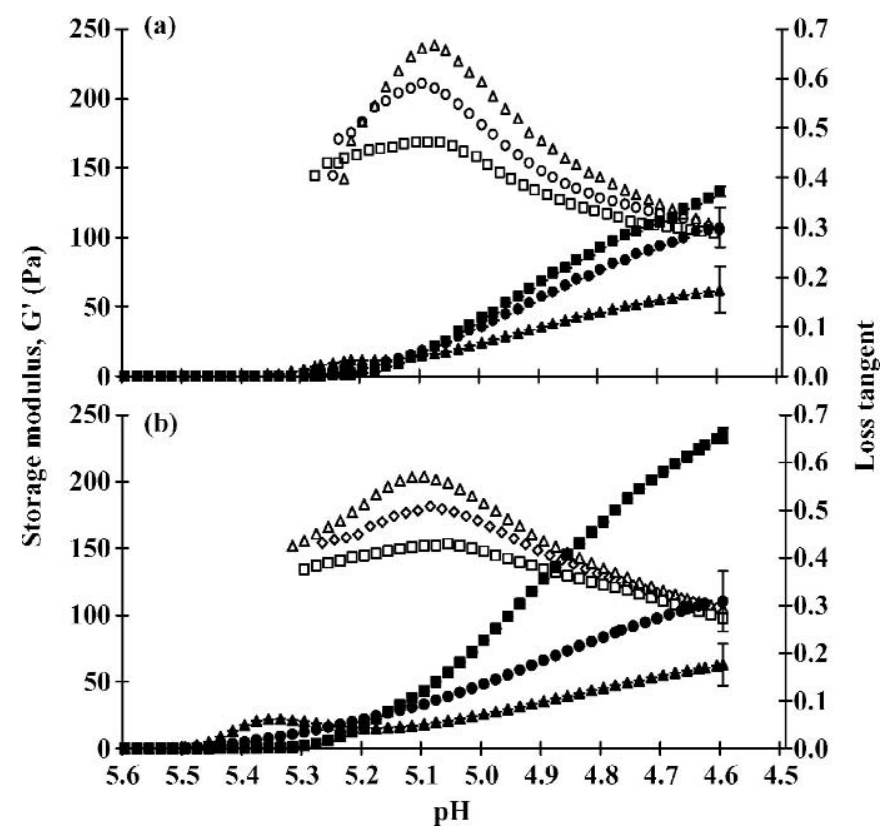

Figure 1. Gelation profiles as a function of $\mathrm{pH}$ for a) yogurt gels made from milk preheated at $75^{\circ} \mathrm{C}$ for 30 min and incubated at $32^{\circ} \mathrm{C}$ $(\square, \square), 38^{\circ} \mathrm{C}(\bullet, \bigcirc)$, and $44^{\circ} \mathrm{C}(\boldsymbol{\Delta}, \triangle)$, and b) yogurt gels made from milk preheated at $85^{\circ} \mathrm{C}$ for $30 \mathrm{~min}$ and incubated at $32^{\circ} \mathrm{C}(\boldsymbol{\square}, \square)$, $38^{\circ} \mathrm{C}(\bullet, \bigcirc)$, and $44^{\circ} \mathrm{C}(\boldsymbol{\Lambda}, \triangle)$. Solid symbols and open symbols indicate storage modulus $\left(\mathrm{G}^{\prime}\right)$ and loss tangent $(\mathrm{LT})$, respectively. Results were the mean of 3 replicates with error bars for the standard deviations.

cating low chalkiness (smooth) and high chalkiness, respectively. Visual particle size was defined as size of residual particles on the back of the spoon after sampling.

\section{Experimental Design and Statistical Analysis}

The effects of milk preheating temperature and incubation temperature on physical and sensory properties of yogurts were studied using a 2 -factor $(3 \times 2)$ ANOVA with 3 replicates. The significance level was determined at $P<0.05$. Using 18 flow curves ( 3 replicates $\times 6$ experimental conditions), the sum of square residuals was calculated to determine the applicability of several rheological models to the flow curves of stirred yogurts. The SAS software (SAS Institute, 1999) was used to perform ANOVA using a GLM and least squares means test used to analyze statistically differences between mean values.

\section{RESULTS}

\section{Yogurt Gel Formation}

The rheological profiles of yogurt gels as the function of $\mathrm{pH}$ are shown in Figure 1. The $\mathrm{pH}$ of milk changed from $\sim 6.5$ to $\sim 4.6$ during fermentation (results not shown). The $\mathrm{G}^{\prime}$ values of yogurt gels preheated at $75^{\circ} \mathrm{C}$ for $30 \mathrm{~min}$ and incubated at 32 or $38^{\circ} \mathrm{C}$ steadily increased after gelation (Figure 1a). Similar types of $\mathrm{G}^{\prime}$ profiles were observed for yogurt gels made from milk preheated at $85^{\circ} \mathrm{C}$ for $30 \mathrm{~min}$ and incubated at 32 or $38^{\circ} \mathrm{C}$ (Figure 1b). However, a clear shoulder was observed on the $\mathrm{G}^{\prime}$ profiles of yogurt gels preheated at 75 or $85^{\circ} \mathrm{C}$ and incubated at $44^{\circ} \mathrm{C}$ (Figure 1 ). The $\mathrm{G}^{\prime}$ values of yogurt gels at $\mathrm{pH} 4.6$ increased with a decrease in incubation temperature (Table 1). There was a decrease in gelation time and an increase in $\mathrm{pH}$ at gelation with an increase in heating and incubation temperatures (Table 1). A maximum in loss tangent $\left(\mathbf{L} \mathbf{T}_{\max }\right.$ ) was present in all yogurt gels between pH 5.0 and 5.1 (Figure 1). The $\mathrm{LT}_{\max }$ values increased as preheating temperature decreased and incubation temperatures increased (Table 1; Figure 1). These trends are in agreement with Lee and Lucey (2004a).

\section{Large Deformation Properties and Permeability of Yogurt Gels}

The changes in apparent viscosity $\left(\eta_{\text {app }}\right)$ of intact yogurt gels as they were subjected to increasing shear rate are shown in Figure 2. As shear rate increased from $\sim 0.1$ to $600 \mathrm{~s}^{-1}$, the $\eta_{\text {app }}$ values of intact yogurt gels decreased (Figure 2) indicating that yogurt gels had shear thinning behavior, as was expected. The $\eta_{\text {app }}$ values of yogurt gels at shear rates between 0.1 and 10 $\mathrm{s}^{-1}$ increased with increasing preheating temperature and decreasing incubation temperature (Table 2 and Figure 2). However, there were no significant differences in the $\eta_{\text {app }}$ values of yogurt gels in the high shear rate region (i.e., $>100 \mathrm{~s}^{-1}$ ).

In the very low shear rate region (i.e., 0.01 to 0.1 $\mathrm{s}^{-1}$ ), the $\eta_{\text {app }}$ values increased with an increase in shear rate before SB was observed (Figure 2). Afonso and Maia (2000) reported a similar trend. The type of flow behavior observed in the very low shear rate region (i.e., 0.01 to $0.1 \mathrm{~s}^{-1}$; Figure 2) could be due to the very short measuring time (i.e., insufficient time to reach a steady state viscosity) or could be due to the viscoelastic nature of the gel (e.g., yield stress). Intact yogurt gels still appear to behave more like elastic solids at the low strains involved in the low shear region. To investigate the effect of time scale of applied deformation, various single, constant shear rates were applied to yogurt gels (Figure 3a). The shear stress $(\sigma)$ values, at the SB point, increased with an increase in shear rates from 0.01 to $0.07 \mathrm{~s}^{-1}$ indicating that resistance by the various bonds in gel network increased with increasing shear rates (Figure 3a). When continuously increasing shear rates were applied to gels, $\sigma$ values initially increased before 
Table 1. Effects of preheating and incubation temperature on the rheological and physical parameters of yogurt gels ${ }^{1}$

\begin{tabular}{lcccccc}
\hline \multicolumn{5}{c}{ Preheating and incubation temperatures } \\
\cline { 2 - 6 } Parameter $^{2}$ & $75^{\circ} \mathrm{C} / 32^{\circ} \mathrm{C}$ & $75^{\circ} \mathrm{C} / 38^{\circ} \mathrm{C}$ & $75^{\circ} \mathrm{C} / 44^{\circ} \mathrm{C}$ & $85^{\circ} \mathrm{C} / 32^{\circ} \mathrm{C}$ & $85^{\circ} \mathrm{C} / 38^{\circ} \mathrm{C}$ & $85^{\circ} \mathrm{C} / 44^{\circ} \mathrm{C}$ \\
\hline $\mathrm{T}_{\mathrm{Gel}}(\min )$ & $325^{\mathrm{a}}$ & $185^{\mathrm{b}}$ & $139^{\mathrm{d}}$ & $309^{\mathrm{a}}$ & $164^{\mathrm{c}}$ & $131^{\mathrm{d}}$ \\
$\mathrm{pH}^{\mathrm{c}}$ at $\mathrm{T}_{\mathrm{Gel}}$ & $5.21^{\mathrm{c}}$ & $5.27^{\mathrm{bc}}$ & $5.35^{\mathrm{b}}$ & $5.31^{\mathrm{b}}$ & $5.47^{\mathrm{a}}$ & $5.50^{\mathrm{a}}$ \\
$\mathrm{T}_{\mathrm{pH} 4.6}(\mathrm{~min})$ & $557^{\mathrm{a}}$ & $314^{\mathrm{c}}$ & $255^{\mathrm{d}}$ & $528^{\mathrm{b}}$ & $311^{\mathrm{c}}$ & $266^{\mathrm{d}}$ \\
$\mathrm{G}^{3}(\mathrm{~Pa})$ & $134^{\mathrm{b}}$ & $107^{\mathrm{c}}$ & $62^{\mathrm{d}}$ & $232^{\mathrm{a}}$ & $110^{\mathrm{bc}}$ & $62^{\mathrm{d}}$ \\
$\mathrm{LT}_{\max }$ & $0.475^{\mathrm{e}}$ & $0.590^{\mathrm{b}}$ & $0.668^{\mathrm{a}}$ & $0.429^{\mathrm{f}}$ & $0.508^{\mathrm{d}}$ & $0.571^{\mathrm{c}}$ \\
$\sigma_{\text {yield }}{ }^{3}(\mathrm{~Pa})$ & $24^{\text {cd }}$ & $33^{\mathrm{bc}}$ & $12^{\mathrm{e}}$ & $53^{\mathrm{a}}$ & $43^{\mathrm{ab}}$ & $18^{\mathrm{de}}$ \\
$\gamma_{\text {yield }}$ & $0.42^{\mathrm{c}}$ & $0.45^{\mathrm{bc}}$ & $0.35^{\mathrm{d}}$ & $0.45^{\mathrm{bc}}$ & $0.49^{\mathrm{ab}}$ & $0.52^{\mathrm{a}}$ \\
$B^{3}\left(10^{-13} \mathrm{~m}^{2}\right)$ & $1.41^{\mathrm{e}}$ & $2.76^{\mathrm{b}}$ & $4.61^{\mathrm{a}}$ & $0.76^{\mathrm{f}}$ & $1.66^{\mathrm{d}}$ & $2.32^{\mathrm{c}}$ \\
\hline
\end{tabular}

${ }^{a-f}$ Different superscripts in the same row are significantly different $(P<0.05)$.

${ }^{1} \mathrm{Gels}$ were prepared by preheating at 75 or $85^{\circ} \mathrm{C}$ for $30 \mathrm{~min}$, followed by incubation at 32,38 , or $44^{\circ} \mathrm{C}$.

${ }^{2} \mathrm{~T}_{\mathrm{Gel}}=$ Gelation time; $\mathrm{T}_{\mathrm{pH} 4.6}=$ time from inoculation to $\mathrm{pH} 4.6 ; \mathrm{G}^{\prime}=$ storage modulus; $\mathrm{LT}_{\max }=$ maximum in loss tangent; $\sigma_{\text {yield }}=$ yield stress; $\gamma_{\text {yield }}=$ yield strain; $B=$ permeability coefficient.

${ }^{3}$ These properties were analyzed when gels were $\mathrm{pH} \sim 4.6$.

eventually decreasing (Figure 3b). Obvious SB occurred at higher shear rates in yogurt gels incubated at 32 and $38^{\circ} \mathrm{C}$ compared with gels incubated at $44^{\circ} \mathrm{C}$ (Table 2 ); this could be due to differences in yield strain in these different gels (Table 1). The $\eta_{\text {app }}$ and $\sigma$ values of yogurt gels at the apparent SB point increased as

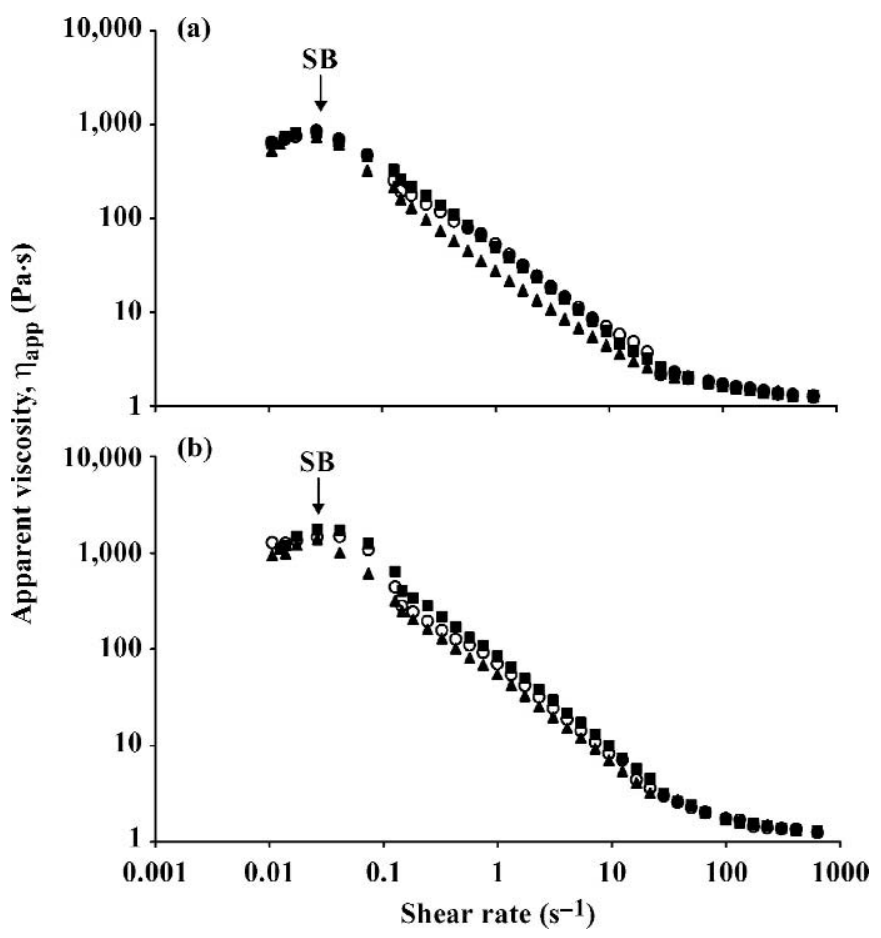

Figure 2. Apparent viscosity as a function of shear rate for a) yogurt gels made from milk preheated at $75^{\circ} \mathrm{C}$ for 30 min and incubated at $32^{\circ} \mathrm{C}(\mathbf{\square}), 38^{\circ} \mathrm{C}(\bigcirc)$, and $44^{\circ} \mathrm{C}(\mathbf{\Delta})$, and b) yogurt gels made from milk preheated at $85^{\circ} \mathrm{C}$ for $30 \mathrm{~min}$ and incubated at $32^{\circ} \mathrm{C}(\boldsymbol{\square})$, $38^{\circ} \mathrm{C}(\bigcirc)$, and $44^{\circ} \mathrm{C}(\boldsymbol{\Delta}) . \mathrm{SB}=$ structural breakdown. Results were the mean of 3 replicates. preheating temperature increased and incubation temperature decreased (Table 2).

The $\sigma_{\text {yield }}$ values of yogurt gels increased with increasing heating temperatures and decreasing incubation temperatures (Table 1), which was a similar trend to the $\sigma$ values of yogurt gels at the apparent SB point (Table 2). An increase in $\gamma_{\text {yield }}$ values were observed with an increase in heating temperatures, whereas there were no significant differences in the $\gamma_{\text {yield }}$ values of yogurt gels incubated at different temperatures (Table 1).

As heating temperatures decreased and incubation temperatures increased, the $B$ values of yogurt gels increased, suggesting that these gels had larger pores (Table 1), in agreement with the trends of Lee and Lucey (2004a).

\section{Rheological Behavior of Stirred Yogurts}

The effects of preheating and incubation temperature on the $\eta_{\text {app }}$ of stirred yogurt are shown in Figure 4. A decrease in $\eta_{\text {app }}$ with increasing shear rate was observed in all stirred yogurts indicating that stirred yogurts exhibited shear-thinning behavior (Figure 4). As shear rate increased from 0.01 to $\sim 50 \mathrm{~s}^{-1}$, the $\eta_{\text {app }}$ of stirred yogurts increased with an increase in preheating temperature and a decrease in incubation temperature (Table 2 and Figure 4).

\section{Adequacy of Various Rheological Models to Fit the Experimental Flow Behavior}

The flow curves of actual (experimental) yogurt gels and predicted flow curves using rheological models are presented in Figure 5. In the very low shear rate region (i.e., 0.01 to $0.1 \mathrm{~s}^{-1}$ ), the flow curve of experimental 
GELATION CONDITIONS IN STIRRED YOGURTS

Table 2. Structural breakdown parameters and apparent viscosities of yogurt gels and stirred yogurts ${ }^{1}$

\begin{tabular}{lcccccc}
\hline & \multicolumn{5}{c}{ Preheating and incubation temperatures } \\
\cline { 2 - 6 } Parameter & $75^{\circ} \mathrm{C} / 32^{\circ} \mathrm{C}$ & $75^{\circ} \mathrm{C} / 38^{\circ} \mathrm{C}$ & $75^{\circ} \mathrm{C} / 44^{\circ} \mathrm{C}$ & $85^{\circ} \mathrm{C} / 32^{\circ} \mathrm{C}$ & $85^{\circ} \mathrm{C} / 38^{\circ} \mathrm{C}$ & $85^{\circ} \mathrm{C} / 44^{\circ} \mathrm{C}$ \\
\hline Yogurt gels & & & & \\
$\eta_{\text {app }}$ at SB $(\mathrm{Pa} \cdot \mathrm{s})$ & $801^{\mathrm{c}}$ & $828^{\mathrm{c}}$ & $727^{\mathrm{c}}$ & $1709^{\mathrm{a}}$ & $1649^{\mathrm{ab}}$ & $1317^{\mathrm{b}}$ \\
Shear rate at SB $\left(\mathrm{s}^{-1}\right)$ & $0.04^{\mathrm{abc}}$ & $0.03^{\mathrm{abc}}$ & $0.02^{\mathrm{c}}$ & $0.05^{\mathrm{a}}$ & $0.04^{\mathrm{ab}}$ & $0.03^{\mathrm{bc}}$ \\
$\sigma$ at $\mathrm{SB}(\mathrm{Pa})$ & $26^{\mathrm{cd}}$ & $28^{\mathrm{bc}}$ & $18^{\mathrm{d}}$ & $39^{\mathrm{a}}$ & $35^{\mathrm{ab}}$ & $32^{\mathrm{abc}}$ \\
$\eta_{\text {app }}$ at $10 \mathrm{~s}^{-1}(\mathrm{~Pa} \cdot \mathrm{s})$ & $6.27^{\mathrm{bc}}$ & $7.03^{\mathrm{b}}$ & $4.44^{\mathrm{c}}$ & $9.93^{\mathrm{a}}$ & $8.28^{\mathrm{ab}}$ & $7.03^{\mathrm{b}}$ \\
$\eta_{\text {app }}$ at $50 \mathrm{~s}^{-1}(\mathrm{~Pa} \cdot \mathrm{s})$ & $2.03^{\mathrm{ab}}$ & $1.99^{\mathrm{b}}$ & $1.98^{\mathrm{b}}$ & $2.40^{\mathrm{a}}$ & $2.27^{\mathrm{ab}}$ & $2.39^{\mathrm{a}}$ \\
$\eta_{\text {app }}$ at $100 \mathrm{~s}^{-1}(\mathrm{~Pa} \cdot \mathrm{s})$ & $1.63^{\mathrm{a}}$ & $1.70^{\mathrm{a}}$ & $1.67^{\mathrm{a}}$ & $1.70^{\mathrm{a}}$ & $1.74^{\mathrm{a}}$ & $1.80^{\mathrm{a}}$ \\
Stirred yogurts & & & & & & \\
$\eta_{\text {app }}$ at $10 \mathrm{~s}^{-1}(\mathrm{~Pa} \cdot \mathrm{s})$ & $1.81^{\mathrm{c}}$ & $1.66^{\mathrm{c}}$ & $1.47^{\mathrm{d}}$ & $2.24^{\mathrm{a}}$ & $2.02^{\mathrm{b}}$ & $2.01^{\mathrm{b}}$ \\
$\eta_{\text {app }}$ at $50 \mathrm{~s}^{-1}(\mathrm{~Pa} \cdot \mathrm{s})$ & $1.40^{\mathrm{c}}$ & $1.33^{\mathrm{d}}$ & $1.31^{\mathrm{d}}$ & $1.59^{\mathrm{a}}$ & $1.54^{\mathrm{ab}}$ & $1.49^{\mathrm{b}}$ \\
$\eta_{\text {app }}$ at $100 \mathrm{~s}^{-1}(\mathrm{~Pa} \cdot \mathrm{s})$ & $1.30^{\mathrm{cd}}$ & $1.28^{\mathrm{d}}$ & $1.31^{\mathrm{cd}}$ & $1.43^{\mathrm{a}}$ & $1.40^{\mathrm{ab}}$ & $1.35^{\mathrm{bc}}$ \\
\hline
\end{tabular}

${ }^{\mathrm{a}-\mathrm{d}}$ Different superscripts in the same row are significantly different $(P<0.05)$.

${ }^{1} \mathrm{Gels}$ were prepared by preheating at 75 or $85^{\circ} \mathrm{C}$ for $30 \mathrm{~min}$, followed by incubation at 32,38 , or $44^{\circ} \mathrm{C}$.

${ }^{2} \mathrm{SB}=$ Structural breakdown; $\eta_{\text {app }}=$ apparent viscosity; $\sigma=$ shear stress.

yogurt gel exhibited a small increase in the $\eta_{\text {app }}$ value, whereas the $\eta_{\text {app }}$ value of the predicted flow curves from Casson, Herschel-Bulkley, Carreau, and Cross models never exhibited an increase in the $\eta_{\text {app }}$ value with an increase in shear rate. The Carreau and Cross models were better fitted with the flow curve of experimental

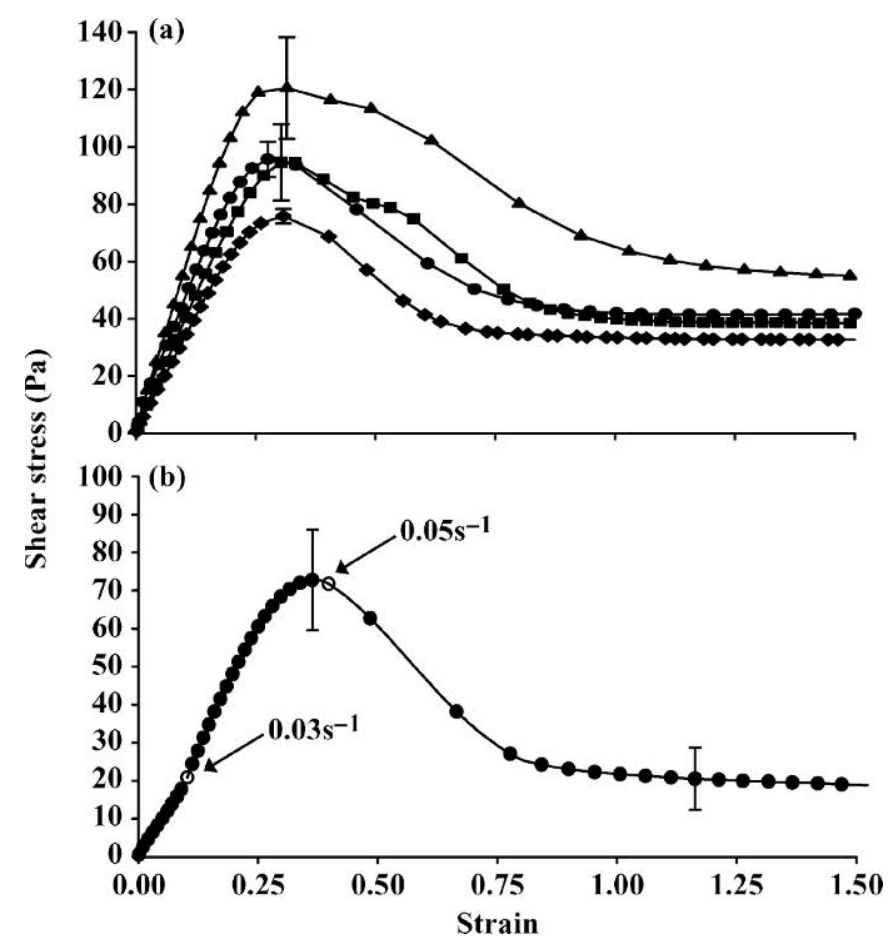

Figure 3. The shear stress as a function of strain at a) constant shear of $0.01 \mathrm{~s}^{-1}(\bullet), 0.03 \mathrm{~s}^{-1}(\mathbf{\square}), 0.05 \mathrm{~s}^{-1}(\bullet)$, and $0.07 \mathrm{~s}^{-1}(\mathbf{\Lambda})$, and b) continuously increasing shear rates from 0.01 to $0.07 \mathrm{~s}^{-1}$ for yogurt gels made from milk preheated at $85^{\circ} \mathrm{C}$ for 30 min and incubated at $38^{\circ} \mathrm{C}$. Arrows indicate shear rates at some points in the process. Results were the mean of 3 replicates with error bars for the standard deviations. yogurt gel compared with the Casson and HerschelBulkley models (Figure 5). Other rheological models such as Blau, Eyring, and Steiger models were also tried, but they were not able to fit this type of flow behavior in the low shear rate region of the experimental yogurt gels (results not shown). Thus, commonly used models for stirred yogurts, including the Casson and Herschel-Bulkley models, could not model the complete shear rate profile of yogurt gels.

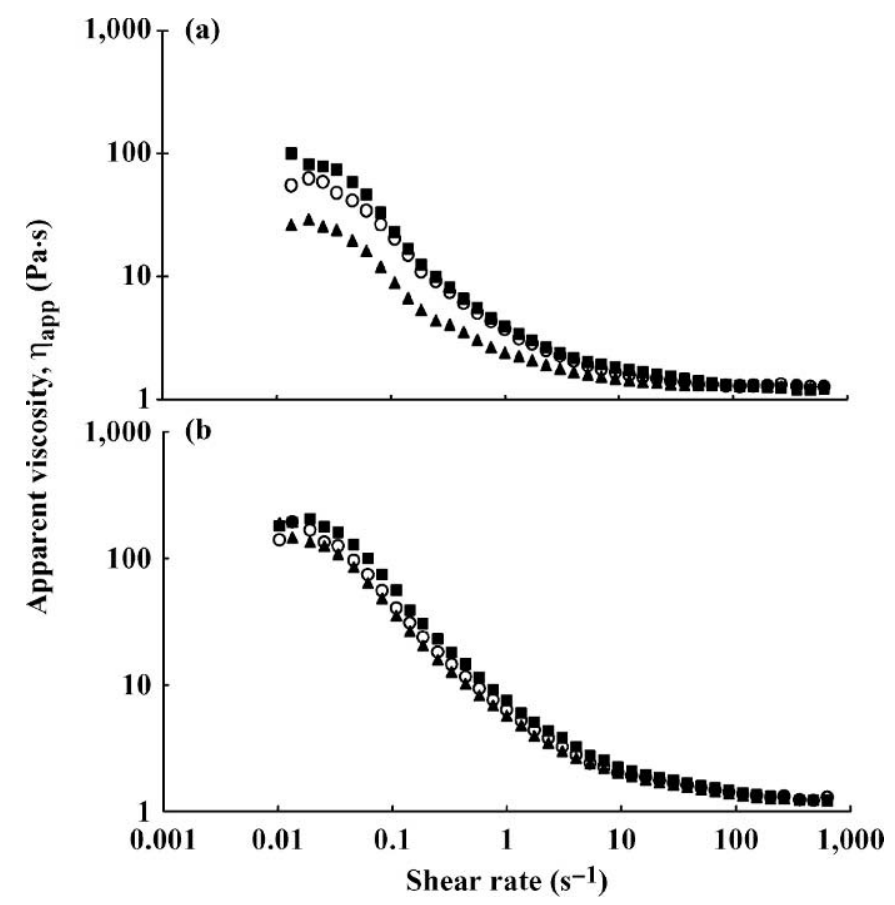

Figure 4. The apparent viscosity as a function of shear rate for a) stirred yogurts made from milk preheated at $75^{\circ} \mathrm{C}$ for $30 \mathrm{~min}$ and incubated at $32^{\circ} \mathrm{C}(\boldsymbol{\square}), 38^{\circ} \mathrm{C}(\bigcirc)$, and $44^{\circ} \mathrm{C}(\boldsymbol{\Delta})$, and b) stirred yogurts made from milk preheated at $85^{\circ} \mathrm{C}$ for $30 \mathrm{~min}$ and incubated at $32^{\circ} \mathrm{C}$ $(\square), 38^{\circ} \mathrm{C}(\bigcirc)$, and $44^{\circ} \mathrm{C}(\boldsymbol{\Lambda})$. Results were the mean of 3 replicates. 


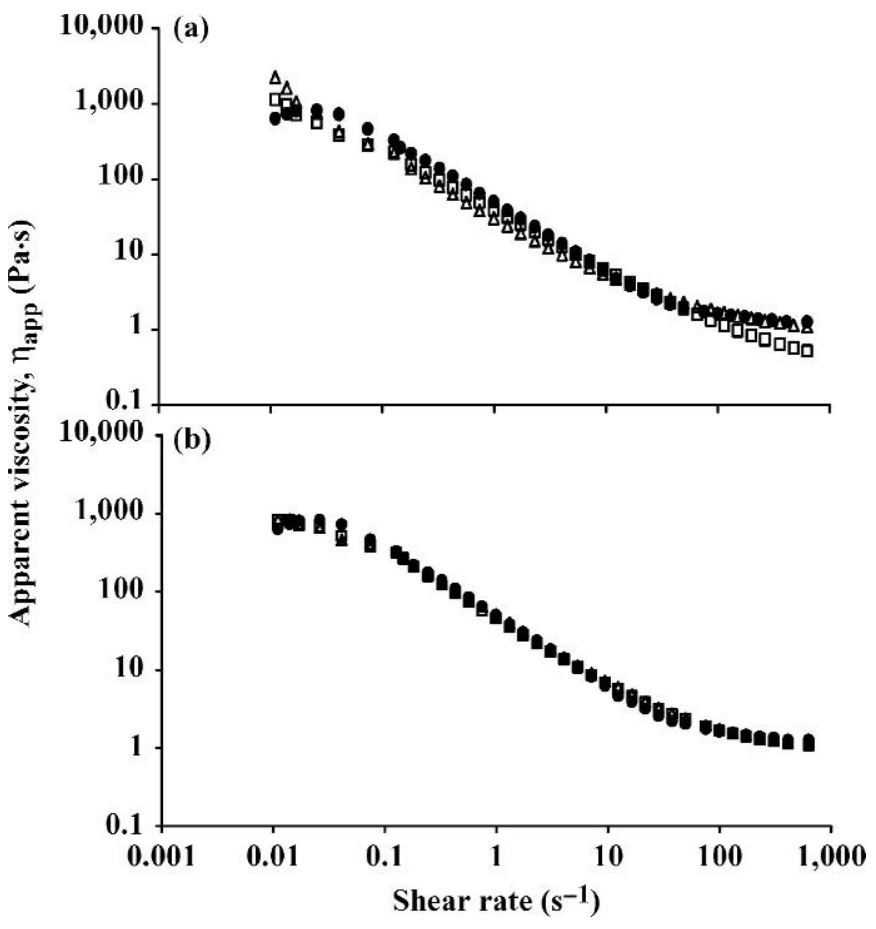

Figure 5. Comparison between experimental flow curves of actual yogurt gels and predicted flow curves using rheological models: a) experimental flow curve of actual yogurt gel $(\bullet)$, predicted flow curve using Herschel-Bulkley model ( $\square$ ), and predicted flow curve using Casson model $(\triangle)$; and b) experimental flow curve of actual yogurt gel $(\bullet)$, predicted flow curves using Carreau model $(\square)$, and predicted flow curve using Cross model $(\triangle)$.

In Table 3, rheological models were tested to investigate their applicability to the flow curves of stirred yogurts shown in Figure 4. The Casson and HerschelBulkley models, which have yield stress terms, were selected to describe the flow behavior of stirred yogurts because stirred yogurts are known to have a yield stress (Ramaswamy and Basak, 1991; van Marle et al., 1999). Both the Casson and Herschel-Bulkley models had a high square of the correlation coefficient values $\left(\mathrm{R}^{2}=\right.$

Table 3. Sum of square residuals and square of correlation coefficients for the apparent viscosity of stirred yogurts using the Casson and Herschel-Bulkley models ${ }^{1}$

\begin{tabular}{lcc}
\hline & \multicolumn{2}{c}{ Models } \\
\cline { 2 - 3 } Shear rate region & $\begin{array}{l}\text { Casson } \\
\left(\mathrm{R}^{2}=0.99\right)\end{array}$ & $\begin{array}{l}\text { Herschel-Bulkley } \\
\left(\mathrm{R}^{2}=0.99\right)\end{array}$ \\
\hline Complete curve $\left(0.01\right.$ to $\left.600 \mathrm{~s}^{-1}\right)$ & $8,411^{\mathrm{a}}$ & $15,123^{\mathrm{b}}$ \\
0.01 to $0.1 \mathrm{~s}^{-1}$ & $8,373^{\mathrm{a}}$ & $15,068^{\mathrm{b}}$ \\
0.1 to $10 \mathrm{~s}^{-1}$ & $37.7^{\mathrm{a}}$ & $55.1^{\mathrm{a}}$ \\
10 to $600 \mathrm{~s}^{-1}$ & $0.2^{\mathrm{a}}$ & $0.1^{\mathrm{b}}$ \\
\hline${ }^{\mathrm{a}, \mathrm{b}}$ Different superscripts in the same row are significantly different \\
$(P<0.05)$. \\
\multicolumn{3}{l}{ Data used for calculations were all the data from 18 flow curves } \\
(3 replicates $\times 6$ experimental conditions).
\end{tabular}

0.99; Table 3). The Casson and Herschel-Bulkley models have often been used to describe the flow behavior of stirred yogurt (Parnell-Clunies et al., 1986; Ramaswamy and Basak, 1991) because these models give high $\mathrm{R}^{2}$ values. However, although these rheological models had high $R^{2}$ values, there could be variation in the residuals indicating a lack of fit in certain regions of the flow profile. The sum of square residual values were determined (Table 3) and the Casson model had significantly lower sum of square residual values than the Herschel-Bulkley model in all shear rate regions (Table 3 ). Thus, the Casson model was more suitable for fitting the flow curves of stirred yogurts compared with the Herschel-Bulkley model. However, the Casson model had much higher sum of square residual values in very low shear rate region (i.e., 0.01 to $0.1 \mathrm{~s}^{-1}$ ) compared with the other shear rate regions, which again indicated that in the low shear rate region, the flow curves of stirred yogurts were less adequately fitted with this rheological model (Table 3).

\section{Microstructure of Yogurt}

The microstructure of yogurt gels and stirred yogurts made with different heating and incubation temperatures are shown in Figures 6 and 7, respectively. A branched and cross-linked protein structure was observed in set yogurts preheated at $85^{\circ} \mathrm{C}$, whereas set yogurts preheated at $75^{\circ} \mathrm{C}$ exhibited thinner strands and clusters in the protein network (Figure 6), in agreement with Lee and Lucey (2004a). At both heating temperatures, set yogurts incubated at $32^{\circ} \mathrm{C}$ had a more interconnected protein structure compared with set yogurts incubated at 38 or $44^{\circ} \mathrm{C}$ (Figure 6). Larger pores were present in microstructures of set yogurts incubated at $44^{\circ} \mathrm{C}$ compared with gels incubated at 32 or $38^{\circ} \mathrm{C}$ (Figure 6).

The microstructure of stirred yogurts is shown in Figure 7. Compared with the initial intact yogurt gels, microstructures of stirred yogurts exhibited much more dense protein aggregates. This is probably due to the stirring process, which mostly destroyed the initial network, and weak aggregates may have formed due to collision of particles. van Marle (1998) reported that concentrated dispersion of gel aggregates was observed in stirred yogurts prepared by stirring yogurt gels with a spoon. There was also probably considerable reformation of (weak) bonds in the stirred products during storage of the samples (in the slide) for $1 \mathrm{~h}$ before microstructural analysis. Stirred yogurts made from milk preheated at $85^{\circ} \mathrm{C}$ had larger clusters of protein aggregates than stirred yogurts made from milk preheated at $75^{\circ} \mathrm{C}$ (Figure 7). More densely packed protein structures were observed in stirred yogurts incubated at 32 

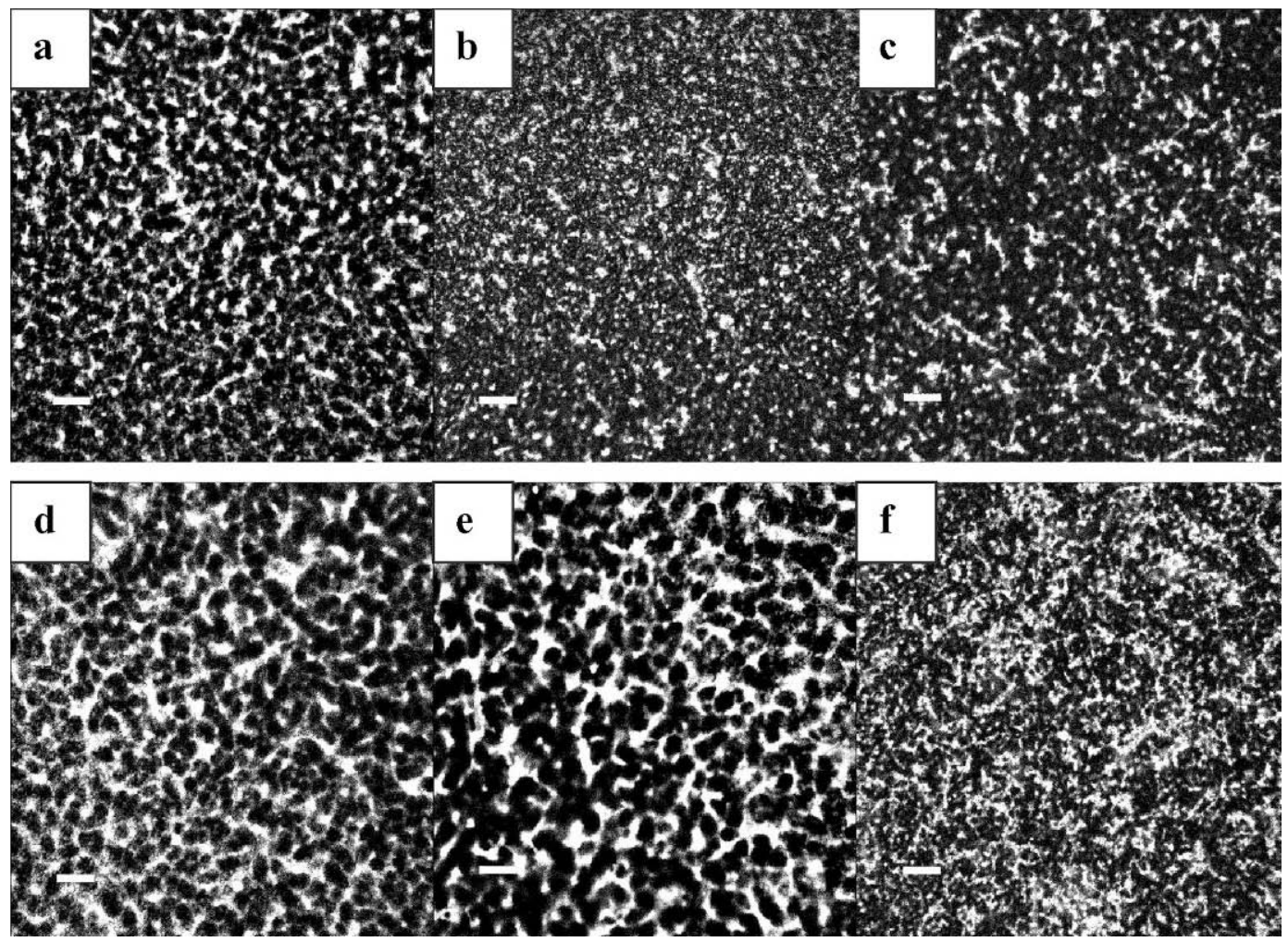

Figure 6. Microstructure for yogurt gels made from milk preheated at $75^{\circ} \mathrm{C}$ for 30 min and incubated at a) 32 , b) 38 , and c) $44^{\circ} \mathrm{C}$; and for yogurt gels made from milk preheated at $85^{\circ} \mathrm{C}$ for 30 min and incubated at d) 32 , e) 38 , and f) $44^{\circ} \mathrm{C}$. Protein matrix is white whereas pores are dark; scale bar $=20 \mu \mathrm{m}$.

or $38^{\circ} \mathrm{C}$ whereas stirred yogurts incubated at $44^{\circ} \mathrm{C}$ had more open protein networks (Figure 7). It seemed that the network of stirred yogurt preheated at $85^{\circ} \mathrm{C}$ and incubated at $32^{\circ} \mathrm{C}$ (Figure $7 \mathrm{~d}$ ) consisted of protein aggregates of smaller size compared with stirred yogurts made from milk preheated at $75^{\circ} \mathrm{C}$ and incubated at $44^{\circ} \mathrm{C}$ (Figure $7 \mathrm{c}$ ).

\section{Sensory Properties of Stirred Yogurts}

Oral viscosity and mouth coating attributes increased as heating temperature increased and incubation temperature decreased (Table 4). Higher chalkiness (or lower smoothness) and larger visual particle size attributes were observed with decreased heating temperatures and increased incubation temperatures (Table 4). Smoothness of stirred yogurt has been reported to decrease as incubation temperatures increase (Cho-AhYing et al., 1990).

\section{Correlations}

Significant correlations were observed between the physical and sensory properties (Table 5). The G'value of yogurt gels was positively correlated with $\sigma_{\text {yield }}, \eta_{\text {app }}$ at $10 \mathrm{~s}^{-1}$ of intact yogurt gels, $\eta_{\text {app }}$ at $10 \mathrm{~s}^{-1}$ of stirred yogurts, oral viscosity, and mouth coating sensory attributes of stirred yogurts, and negatively correlated with $B$ (Table 5). The $\mathrm{LT}_{\max }$ value was positively correlated with $B$ and chalkiness, whereas $\mathrm{LT}_{\max }$ was negatively correlated with $\sigma_{\text {yield }}, \eta_{\text {app }}$ at $10 \mathrm{~s}^{-1}$ of intact yogurt gels, $\eta_{\text {app }}$ at $10 \mathrm{~s}^{-1}$ of stirred yogurts, oral viscosity, and mouth coating sensory properties of stirred yogurts (Table 5). Positive correlations were observed between $B$ and chalkiness, whereas $B$ was negatively correlated with $\sigma_{\text {yield }}, \eta_{\text {app }}$ at SB, $\sigma$ at SB, $\eta_{\text {app }}$ at $10 \mathrm{~s}^{-1}$ of intact yogurt gels, $\eta_{\text {app }}$ at 10 and $50 \mathrm{~s}^{-1}$ of stirred yogurts, oral viscosity, and mouth coating sensory attributes of stirred yogurts (Table 5). Yield stress, $\sigma_{\text {yield }}$, was positively correlated with $\eta_{\text {app }}$ at SB, $\sigma$ at SB, $\eta_{\text {app }}$ at $10 \mathrm{~s}^{-1}$ of intact yogurt gels, $\eta_{\text {app }}$ at 10 and $50 \mathrm{~s}^{-1}$ of stirred yogurts, oral viscosity, and mouth coating sensory attributes (Table 5).

\section{DISCUSSION}

This study was performed to determine how the structure of the initial gel network and SB process af- 


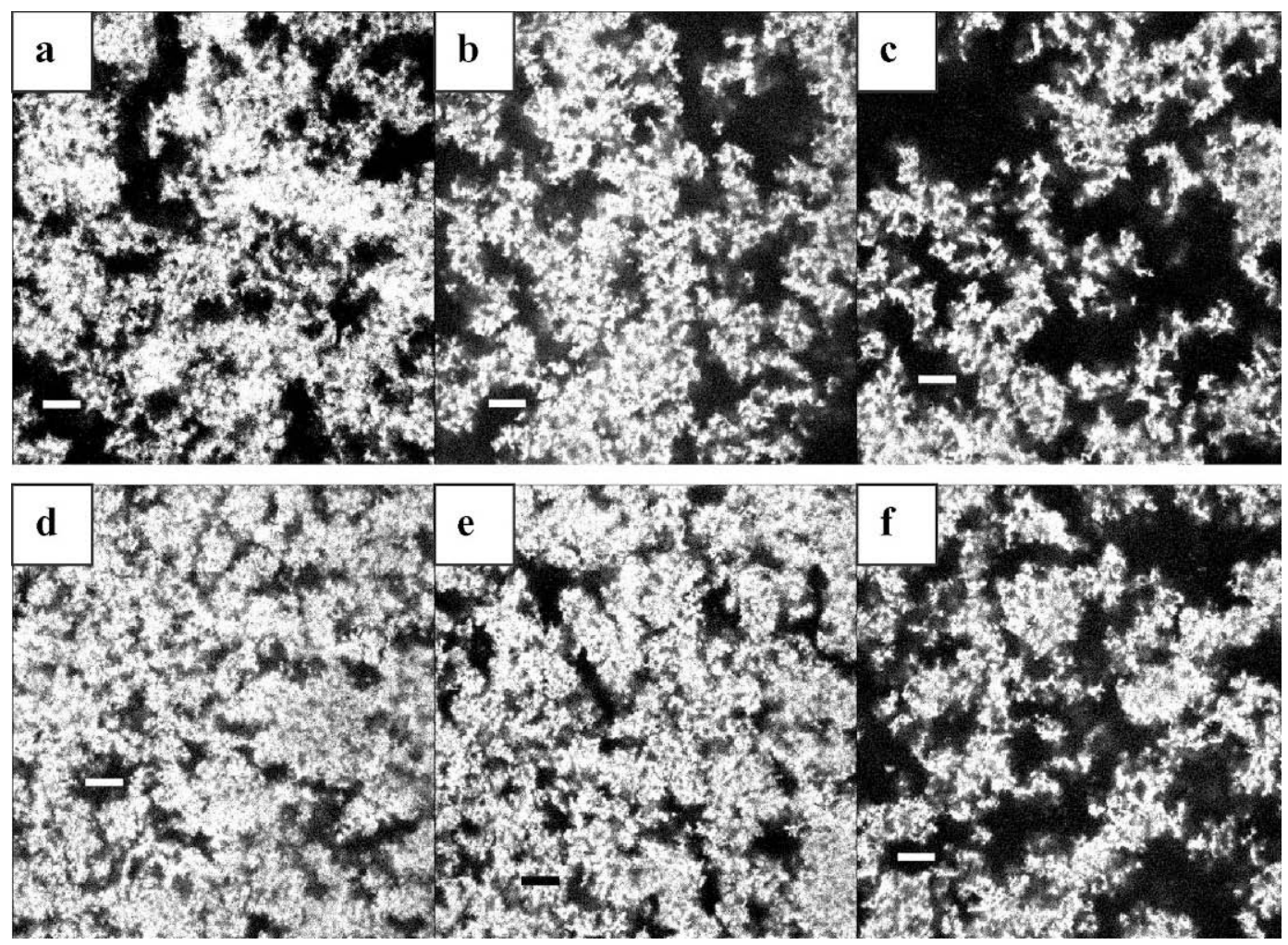

Figure 7. Microstructure for stirred yogurts made from milk preheated at $75^{\circ} \mathrm{C}$ for 30 min and incubated at a) 32 , b) 38 , and c) $44^{\circ} \mathrm{C}$; and for stirred yogurts made from milk preheated at $85^{\circ} \mathrm{C}$ for 30 min and incubated at d) 32 , e) 38 , and f) $44^{\circ} \mathrm{C}$. Protein matrix is white whereas pores are dark; scale bar $=20 \mu \mathrm{m}$.

fected the physical and sensory properties of stirred yogurt made from these gels. Milk preheating temperature and incubation temperature were selected as processing variables because yogurt manufacturers can easily use these variables to change their physical and sensory attributes. It is also known that these variables greatly influence yogurt texture (e.g., Lee and Lucey, 2004a) and preheat treatment of milk at $\geq 80^{\circ} \mathrm{C}$ for 30 min resulted in a great increase in denaturation of whey protein compared with that of milk preheated at $75^{\circ} \mathrm{C}$ for $30 \mathrm{~min}$ (Lucey et al., 1997a). In general, the use of higher preheating temperature and lower incubation temperature resulted in increased $\eta_{\text {app }}$ values (Table 2 and Figure 2). There were significant positive correlations between $\mathrm{G}^{\prime}$ and $\sigma_{\text {yield }}$ and $\eta_{\text {app }}$ at $10 \mathrm{~s}^{-1}$ (Table 5). Increased $\mathrm{G}^{\prime}$ and $\sigma_{\text {yield }}$, and $\eta_{\text {app }}$ values in gels can be attributed to increased strength and number of bonds in the gel network and stronger interactions between protein particles (van Vliet et al., 1991, 1997; Lucey et al., 1997a).

An increase in the $\eta_{\text {app }}$ of initial yogurt gels before SB was observed in gels when tested in the very low shear rate region (i.e., 0.01 to $0.1 \mathrm{~s}^{-1}$; Figure 2). The $\sigma$ values at the SB point increased as shear rates increased from 0.01 to $0.07 \mathrm{~s}^{-1}$ (Figure 3a). A similar type of stress overshoot behavior has been observed in model

Table 4. Effects of preheating and incubation temperature on the sensory parameters of stirred yogurts ${ }^{1}$

\begin{tabular}{lllllll}
\hline & \multicolumn{5}{c}{ Preheating and incubation temperatures } \\
\cline { 2 - 6 } Sensory attribute & $75^{\circ} \mathrm{C} / 32^{\circ} \mathrm{C}$ & $75^{\circ} \mathrm{C} / 38^{\circ} \mathrm{C}$ & $75^{\circ} \mathrm{C} / 44^{\circ} \mathrm{C}$ & $85^{\circ} \mathrm{C} / 32^{\circ} \mathrm{C}$ & $85^{\circ} \mathrm{C} / 38^{\circ} \mathrm{C}$ & $85^{\circ} \mathrm{C} / 44^{\circ} \mathrm{C}$ \\
\hline Oral viscosity & $7.2^{\mathrm{c}}$ & $6.6^{\mathrm{d}}$ & $5.6^{\mathrm{e}}$ & $8.9^{\mathrm{a}}$ & $8.1^{\mathrm{b}}$ & $6.6^{\mathrm{d}}$ \\
Mouth coating & $7.0^{\mathrm{bc}}$ & $6.0^{\mathrm{d}}$ & $5.6^{\mathrm{d}}$ & $7.9^{\mathrm{a}}$ & $7.5^{\mathrm{ab}}$ & $6.6^{\mathrm{c}}$ \\
Chalkiness & $7.2^{\mathrm{ab}}$ & $7.5^{\mathrm{a}}$ & $7.7^{\mathrm{a}}$ & $6.6^{\mathrm{c}}$ & $6.8^{\mathrm{bc}}$ & $7.5^{\mathrm{a}}$ \\
Visual particles & $6.8^{\mathrm{bc}}$ & $7.3^{\mathrm{ab}}$ & $7.6^{\mathrm{a}}$ & $6.5^{\mathrm{c}}$ & $6.7^{\mathrm{c}}$ & $7.4^{\mathrm{ab}}$ \\
\hline
\end{tabular}

${ }^{\mathrm{a}-\mathrm{e}}$ Different superscripts in the same row are significantly different $(P<0.05)$.

${ }^{1}$ Gels were prepared by preheating at 75 or $85^{\circ} \mathrm{C}$ for $30 \mathrm{~min}$, followed by incubation at 32,38 , or $44^{\circ} \mathrm{C}$. 
Table 5. Pearson correlation coefficients between dependent variables ${ }^{1}$

\begin{tabular}{|c|c|c|c|c|c|c|c|c|}
\hline & $\mathrm{G}^{2}$ & $\mathrm{LT}_{\max }^{2}$ & $B^{2}$ & $\sigma_{\text {yield }}^{2}$ & $\eta_{\text {app }}$ at $\mathrm{SB}^{2}$ & $\sigma$ at $\mathbf{S B}^{2}$ & $\begin{array}{l}\text { Oral } \\
\text { viscosity }^{3}\end{array}$ & $\begin{array}{l}\text { Mouth } \\
\text { coating }\end{array}$ \\
\hline$B^{2}$ & $-0.74 * * *$ & $0.97 * * *$ & - & - & - & - & - & - \\
\hline$\sigma_{\text {yield }}{ }^{2}$ & $0.83^{* * *}$ & $-0.73 * * *$ & $-0.72 * * *$ & - & - & - & - & - \\
\hline$\eta_{\text {app }}$ at $\mathrm{SB}^{2}$ & - & - & $-0.62^{* *}$ & $0.65^{* *}$ & - & - & - & - \\
\hline$\sigma$ at $\mathrm{SB}^{2}$ & - & $-0.68 * *$ & $-0.73^{* * *}$ & $0.72^{* * *}$ & - & - & - & - \\
\hline Oral viscosity ${ }^{3}$ & $0.77 * * *$ & $-0.85^{* * *}$ & $-0.84^{* * *}$ & $0.82 * * *$ & $0.63^{* *}$ & $0.70^{* *}$ & - & - \\
\hline Mouth coating ${ }^{3}$ & $0.72^{* * *}$ & $-0.88 * * *$ & $-0.86 * * *$ & $0.75^{* * *}$ & $0.63^{* *}$ & $0.74 * * *$ & - & - \\
\hline Chalkiness $^{3}$ & - & $0.68 * *$ & $0.61^{* *}$ & - & - & - & - & - \\
\hline$\eta_{\mathrm{app}}^{2}$ at $10 \mathrm{~s}^{-1}$ & $0.61^{* *}$ & $-0.71 * *$ & $-0.73 * * *$ & $0.72 * * *$ & $0.78 * * *$ & $0.85^{* * *}$ & $0.74 * * *$ & $0.63^{* *}$ \\
\hline$\eta_{\text {app }}{ }^{3}$ at $10 \mathrm{~s}^{-1}$ & $0.61^{* *}$ & $-0.78 * * *$ & $-0.82^{* * *}$ & $0.69 * *$ & $0.82 * * *$ & $0.89^{* * *}$ & $0.75^{* * *}$ & $0.81 * * *$ \\
\hline$\eta_{\mathrm{app}}{ }^{3}$ at $50 \mathrm{~s}^{-1}$ & - & $-0.74 * * *$ & $-0.77 * * *$ & $0.64^{* *}$ & $0.89^{* * *}$ & $0.81^{* * *}$ & $0.78^{* * *}$ & $0.79 * *$ \\
\hline
\end{tabular}

particle gels (Whittle and Dickinson, 1997). When very low shear rates were initially applied to gels, protein bonds in network may have more time to relax, resulting in a reduction of the stress generated. However, as slightly higher shear rates are applied, there would be less time for protein bonds to relax, resulting in higher shear stress values (Whittle and Dickinson, 1997). During shearing, there is both bond relaxation (breakage) and bond reformation. In the very low shear rate region, the intact gel has substantial resistance (i.e., a yield stress) that must first be overcome before yielding becomes dominant. At some point, the applied shear causes yielding of the network (i.e., breakdown of bonds occurs faster than reformation of bonds); this is the SB point. The viscoelastic nature of intact gels indicates that models that are designed to fit viscosity as a function of shear rate behavior of liquids will not be able to account for the elastic nature of gels at low shear rates (i.e., very low strains). Above the SB point, models commonly used for flow behavior were able to fit the viscosity behavior because yogurt had been converted into a viscous dispersion of casein particles.

The initial (intact) yogurt gels made with low milk heating temperature and high incubation temperature had low $\eta_{\text {app }}$ and $\sigma$ values at the apparent SB point (Table 2), which indicated that these yogurt gels had weaker protein networks. High $\mathrm{LT}_{\max }$ values may be associated with increased possibility of rearrangement of bonds in gel network (van Vliet et al., 1991; Lucey, 2001). Significant negative correlations were observed between $\mathrm{LT}_{\max }$ and $B$ and $\sigma$ values at $\mathrm{SB}$ (Table 5), suggesting that extensive rearrangement of protein particles in gel network may be associated with increased local breakage of protein strands that make up the junctions in the network (van Vliet et al., 1997; van Vliet, 2000). This may result in the formation of weak spots and a less stable gel network.
Unlike intact yogurt gels, an apparent SB point could not be observed in most stirred yogurts although stirred yogurt made with $85^{\circ} \mathrm{C}$ preheating temperature and $38^{\circ} \mathrm{C}$ incubation temperature had an apparent SB point (Figure 4). In stirred yogurt, initial gel networks are mostly disrupted during the stirring process. Although considerable reformation of weak protein bonds could occur during the 1-h waiting time before starting the rheological test, in the very low shear rate region (i.e., 0.01 to $0.1 \mathrm{~s}^{-1}$ ), stirred yogurts probably have substantially less resistance to the applied shear compared with intact yogurt gels. It is also possible that an apparent SB point in stirred yogurts may be observed in the extremely low shear rate region (e.g., $<0.01 \mathrm{~s}^{-1}$ ), but may be rapidly destroyed at higher shear rates.

The $\eta_{\text {app }}$ of stirred yogurts increased with increasing preheating temperature and decreasing incubation temperature in the shear rate region from 0.01 to $\sim 50$ $\mathrm{s}^{-1}$ (Table 2 and Figure 4). Cayot et al. (2003) used the Ostwald model to determine the consistency index of stirred acid gels, and reported that the consistency index increased as preheating temperature increased from 70 to $100^{\circ} \mathrm{C}$ for holding times of 1,4 , or $8 \mathrm{~min}$. When a Posthumus funnel was used to determine the viscosity of stirred yogurt, the use of low incubation temperatures resulted in higher viscosities (Beal et al., 1999; Martin et al., 1999). In stirred yogurts, an increase in oral viscosity sensory attributes and a decrease in chalkiness sensory attributes were observed in samples made from higher preheating and lower incubation temperatures (Table 4). Skriver et al. (1999) reported that oral and nonoral viscosity increased with an increase in preheating temperature while an increase in nonoral viscosity was observed in stirred yogurts incubated at lower temperature. The use of lower yogurt incubation temperature has resulted in higher mouth-coating sensory attribute (Martin et al., 1999). 
In this study, the structure of the initial gel network and the disruption/breakdown process used to convert the initial gel into the dispersed stirred yogurt system affected the physical and sensory properties of stirred yogurts, as indicated by significant relationships between the properties of the initial gel and stirred yogurts (Table 5). Increased protein-protein interactions resulted in increased stiffness of the initial gels (i.e., increased $\mathrm{G}^{\prime}$ and $\sigma_{\text {yield }}$ values), which could contribute to increased $\eta_{\text {app }}$ values and sensory attributes, such as oral viscosity and mouth coating, of stirred yogurts made from these gels. In the preparation of stirred yogurts, during stirring, initial gels may be converted into a dispersed phase at weak spots in gel network where large pores are present (van Marle, 1998). An increased susceptibility of the gel network to rearrangements, as indicated by increased $\mathrm{LT}_{\max }$ and $B$ values, may lead to local breakage of protein strands, which may result in weaker interactions between protein particles and weak spots (van Vliet et al., 1997; van Vliet, 2000). Therefore, stirred yogurts made from these weak gels could have lower $\eta_{\text {app }}$ values and oral viscosity. Initial gels that had less branching and cross-linking protein network and larger pores (i.e., higher $B$ ) produced stirred yogurt that had less dense protein aggregates and lower viscosity.

\section{CONCLUSIONS}

The results of the present study demonstrate that the physical and structural properties of initial yogurt gels, including the number and strength of bonds in gel network, $B$, and the SB process affected the physical and sensory properties of stirred yogurts. Initial yogurt gels that had weaker protein networks and more extensive rearrangement of protein particles in their networks (as indicated by lower $\mathrm{G}^{\prime}$ values and higher $\mathrm{LT}_{\max }$ and $B$ values) produced stirred yogurts with lower $\eta_{\text {app }}$ and oral viscosity sensory attributes. A stress overshoot type of phenomena was observed in very low shear rate region (i.e., 0.01 to $0.1 \mathrm{~s}^{-1}$ ) due to substantial resistance from intact network (i.e., its elastic nature). The flow curves of stirred yogurts were more suitably described by the Casson model compared with the Herschel-Bulkley model but none of the rheological models predicted the increase in $\eta_{\text {app }}$ in the very low shear rate region. The use of higher milk preheating temperature (e.g., $85^{\circ} \mathrm{C}$ ) and lower incubation temperature (e.g., $32^{\circ} \mathrm{C}$ ) resulted in stirred yogurts with higher $\eta_{\text {app }}$, oral viscosity, and smoothness sensory attributes.

\section{ACKNOWLEDGMENTS}

This study was funded by the USDA Cooperative State Research, Education, and Extension Service
(CSREES) project WIS04363. The authors would like to thank Peter Crump for assistance with statistical analysis, and Kate Lim for assistance with sensory tests.

\section{REFERENCES}

Afonso, I. M., and J. M. Maia. 1999. Rheological monitoring of structure evolution and development in stirred yoghurt. J. Food Eng. 42:183-190.

Afonso, I. M., and J. M. Maia. 2000. Rheological monitoring of structure development and rebodying of set-style yoghurt. Appl. Rheol. 10:73-79.

Beal, C., J. Skokanova, E. Latrille, N. Martin, and G. Corrieu. 1999. Combined effects of culture conditions and storage time on acidification and viscosity of stirred yogurt. J. Dairy Sci. 82:673-681.

Bourne, M. C. 2002. Food Texture and Viscosity: Concept and Measurement. 2nd ed. Academic Press, San Diego, CA.

Bradley, R. L., E. Arnold, D. M. Barbano, R. G. Semerad, D. E. Smith, and B. K. Vines. 1992. Chemical and physical methods. Pages 433-531 in Standard Methods for the Examination of Dairy Products. R. T. Marshall, ed. 16th ed. American Public Health Association, Washington, DC.

Cayot, P., J. F. Fairise, B. Colas, D. Lorient, and G. Brule. 2003. Improvement of rheological properties of firm acid gels by skim milk heating is conserved after stirring. J. Dairy Res. 70:423-431.

Cho-Ah-Ying, F., C. L. Duitschaever, and C. Buteau. 1990. Influence of temperature of incubation on the physico-chemical and sensory quality of yoghurt. Cult. Dairy Prod. J. 8:11-14.

Haque, A., R. K. Richardson, and E. R. Morris. 2001. Effect of fermentation temperature on the rheology of set and stirred yogurt. Food Hydrocoll. 15:593-602.

Lawless, H. T., and H. Heymann. 1998. Sensory Evaluation of Food: Principles and Practices. Chapman and Hall, New York, NY.

Lee, W. J., and J. A. Lucey. 2004a. Rheological properties, whey separation, and microstructure in set-style yogurt: Effects of heating temperature and incubation temperature. J. Texture Stud. $34: 515-536$.

Lee, W. J., and J. A. Lucey. 2004b. Structure and physical properties of yogurt gels: Effect of inoculation rate and incubation temperature. J. Dairy Sci. 87:3153-3164.

Lucey, J. A. 2001. The relationship between rheological parameters and whey separation in milk gels. Food Hydrocoll. 15:603-608.

Lucey, J. A. 2004. Cultured dairy products: An overview of their gelation and texture properties. Int. J. Dairy Technol. 57:77-84.

Lucey, J. A., M. Tamehana, H. Singh, and P. A. Munro. 1998. A comparison of the formation, rheological properties and microstructure of acid skim milk gels made with a bacterial culture or glucono- $\delta$-lactone. Food Res. Int. 31:147-155.

Lucey, J. A., C. T. Teo, P. A. Munro, and H. Singh. 1997a. Rheological properties at small (dynamic) and large (yield) deformations of acid gels made from heated milk. J. Dairy Res. 64:591-600.

Lucey, J. A., T. van Vliet, K. Grolle, T. Geurts, and P. Walstra. 1997b. Properties of acid casein gels made by acidification with glucono$\delta$-lactone. 1. Rheological properties. Int. Dairy J. 7:381-388.

Martin, N. C., J. Skokanova, E. Latrille, C. Beal, and G. Corrieu. 1999. Influence of fermentation and storage conditions on the sensory properties of plain low fat stirred yogurts. J. Sens. Stud. 14:139-160.

Mezger, T. G. 2002. The Rheology Handbook. Vincentz Verlag, Hanover, Germany.

Parnell-Clunies, E. M., Y. Kakuda, and J. M. Deman. 1986. Influence of heat treatment of milk on the flow properties of yoghurt. J. Food Sci. 51:1459-1462.

Ramaswamy, H. S., and S. Basak. 1991. Rheology of stirred yogurts. J. Texture Stud. 22:231-241.

Roefs, S. P. F. M., A. E. A. de Groot-Mostert, and T. van Vliet. 1990. Structure of acid casein gels. 1. Formation and model of gel network. Colloids Surfaces. 50:141-159.

SAS Institute. 1999. SAS/STAT User's Guide. 8.0 ed. SAS Institute, Inc., Cary, NC. 
Skriver, A. 1995. Characterization of stirred yoghurt by rheology, microscopy and sensory analysis. Ph.D. Thesis, The Royal Veterinary and Agricultural University.

Skriver, A., J. Holstborg, and K. B. Qvist. 1999. Relation between sensory texture analysis and rheological properties of stirred yogurt. J. Dairy Res. 66:609-618.

Skriver, A., H. Roemer, and K. B. Qvist. 1993. Rheological characterization of stirred yoghurt: Viscometry. J. Texture Stud. 24:185-198.

Tamime, A. Y., and R. K. Robinson. 1999. Yoghurt: Science and Technology. 2nd ed. CRC Press, Boca Raton, FL.

van Marle, M. E. 1998. Structure and rheological properties of yogurt gels and stirred yogurts. Ph.D. Thesis, Wageningen University, The Netherlands.

van Marle, M. E., D. van den Ende, C. G. de Kruif, and J. Mellema. 1999. Steady-shear viscosity of stirred yogurts with varying ropiness. J. Rheol. 43:1643-1662.

van Marle, M. E., and P. Zoon. 1995. Permeability and rheological properties of microbially and chemically acidified skim-milk gels. Neth. Milk Dairy J. 49:47-65. van Vliet, T. 2000. Structure and rheology of gels formed by aggregated protein particles. Pages 367-377 in Hydrocolloids. Part 1. K. Nishinari, ed. Elsevier Applied Science, Amsterdam, The Netherlands.

van Vliet, T., J. A. Lucey, K. Grolle, and P. Walstra. 1997. Rearrangements in acid- induced casein gels during and after gel formation. Pages 335-345 in Food Colloids: Protein, Lipids, and Polysaccharides. E. Dickinson and B. Bergenstahl, ed. Royal Society of Chemistry, Cambridge, UK

van Vliet, T., H. J. M. van Dijk, P. Zoon, and P. Walstra. 1991. Relation between syneresis and rheological properties of particle gels. Colloid Poly. Sci. 269:620-627.

van Vliet, T., and P. Walstra. 1995. Large deformation and fracture behavior of gels. Faraday Discuss. 101:359-370.

Walstra, P. 1998. Relation between structure and texture of cultured milk products. Pages 9-15 in Texture of Fermented Milk Products and Dairy Desserts. Special Issue 9802. International Dairy Federation, Brussels, Belgium.

Whittle, M., and E. Dickinson. 1997. Stress overshoot in a model particle gel. J. Chem. Phys. 107:10191-10200. 